\title{
Mycobiota of outdoor air that can cause asthma: a case study from Lake Manzala, Egypt
}

\author{
Abdel-Azeem $\mathbf{A M}^{1} *$ and Rashad $\mathbf{H M}^{2}$ \\ ${ }^{1}$ Laboratory of systematic Mycology, Botany and Microbiology Department, Faculty of Science, University of Suez \\ Canal, Ismailia 41522,Egypt.e-mail:zemo3000@yahoo.com,ahmed_abdelazeem@science.suez.edu.eg \\ ${ }_{2}^{2}$ Ashtoum El-Gamil protectorate, Egyptian Environmental Affair Agency, Port-Said, Egypt
}

Abdel-Azeem AM, Rashad MH - Mycobiota of outdoor air that can cause asthma: a case study from Lake Manzala, Egypt. Mycosphere 4(6), 1092-1104, Doi 10.5943/mycosphere/4/6/7

\begin{abstract}
Continuous sampling of airspora in Lake Manzala was carried out monthly over a period of 1 year at five sites with an automated air sampler on Czapek's yeast extract, DG-18 and potato dextrose agar media plates. A total of 71780 mould- and 560 yeast colony-forming units were recovered from 600 exposures and the isolated taxa were assigned to 28 genera and 43 species. A greater presence of fungal spores occurred in the summer. Aspergillus niger, Cladosporium cladosporioides, Epicoccum nigrum, Aureobasidium pullulans, Alternaria cheiranthi, Penicillium chrysogenum, Aspergillus fumigatus and Alternaria alternata were the predominant species. Many of the identified species have an aerodynamic diameter $\left(\mathrm{d}_{\mathrm{ae}}\right)$ of 1.5-10 $\mu \mathrm{m}$ that can deeply penetrate into the lungs. Aspergillus, Cladosporium, Penicillium, and Alternaria that had the greatest frequencies in air of Lake Manzala are strongly associated with allergic respiratory disease, especially asthma, in Port Said and Ismailia governorates. A comprehensive model of factors that contribute to asthma in the region is needed and this can be a useful tool for planning efforts and disease prevention. The obtained results indicated that the fungi of air should be considered when the quality of Egyptian air is assessed.
\end{abstract}

Key words - Aerodynamic diameter - aeromycobiota- allergy - diversity - Protectorate

\section{Introduction}

Manzala's lagoon is the largest body of brackish water $\left(\sim 1071 \mathrm{~km}^{2}\right)$ of the Nile Delta coastal lakes. The lagoon has a rhombohedral-shape formed in the actively subsiding delta plain (Stanley 1988), and is shallow, with a depth rarely exceeding one meter (Tahoun 2007). It lies between $31^{\circ}$ $00^{\prime \prime}$ and $31^{\circ} 30^{\prime \prime}$ latitude and $31^{\circ} 45^{\prime \prime}$ and $32^{\circ} 20^{\prime \prime}$ longitude, in the northern quadrant of the delta between the Mediterranean Sea to the north, the Suez Canal, Port Said and Ismailia governorates to the east, the Damietta Branch of the River Nile and the governorates of Sharkiya and Dakahliya to the west (Zahran 2010). The total population of the governorates and their surrounds overlooking the Manzala lagoon is 14514000 (http://www.citypopulation.de/Egypt.html). It is connected with the Mediterranean Sea by five straits, permitting the exchange of water and biota between the lake and the sea (Rashad and Abdel-Azeem 2010). The Lake is considered an important and valuable natural resource ecosystem for fish catch, wildlife, hydrological and biological regime in Egypt. 
Lake Manzala attracts attention of many scientists because of its important economical aspects. Rashad and Abdel-Azeem (2010) listed a set of 447 references that could be considered an updated bibliography on Lake Manzala published during the last two hundred years, out of which 8 references were about fungi.

Research on mycobiota of the protected areas in Egypt is accumulating in the last decade but with little or no concern is given to air fungi as a group playing an important role in the environment except the sole study carried by Abdel-Azeem (2009) on mycobiota of different habitats in Saint Katherine Protectorate.

In other parts of Egypt, little attention has been paid to outdoor airborne mycobiota (Saad 1958, Zaky 1960, Moustafa 1971, Moubasher and Moustafa 1974, Abdel-Hafez et al. 1986). Airborne fungal concentrations have been monitored in some Egyptian cities including Ismailia (Abdul Wahid et al. 1996, Abdel-Azeem 2003), Cairo (Abdel Hameed et al. 1999), Menofia (Abdel Hameed and Khoder 2001), Western Desert (Ismail et al. 2002), Giza (Abdel Hameed et al. 2007), and New Damietta (El-Morsy 2006). Diurnal distribution of airborne fungi was only studied in Upper Egypt, at Assiut (Abu-El-Souod 1974), Qena (Abdel-Fattah et al. 1981) and Helwan (Abdel Hameed et al. 2009).

Airborne fungi have been found to be associated with certain respiratory illneses and allergies (Kowalski and Bahnfleth 1998), while exposure to fungi and other microbes, their fragments and metabolites may constitute a health risk: for example, increases in asthma attacks and bronchial hyperactivity and other respiratory symptoms such as lung cancer have been correlated to increased microbial and particulate levels in the aerosphere (Ross et al. 2000). More than 80 genera of fungi have been linked with symptoms of respiratory tract allergies (Horner et al. 1995), with the most common allergenic genera being Cladosporium, Alternaria, Aspergillus and Fusarium. Exposure to large concentrations of the spores of these four genera causes aspergillosis (Anderson et al. 1996), asthma and pneumonitis (Cuijpers et al. 1995, Hu et al. 1997), allergic alveolitis and toxicosis (Flannigan et al. 1991).

Asthma is one of the most common chronic diseases in the world; with reported estimates of 300 million people worldwide currently having asthma, and suggesting that such figure increases by $50 \%$ every decade (Masoli et al. 2004). Many environmental risk factors are thought to play an important role in asthma e.g. dust mites, pet dander, cockroaches and fungi among others (Bush 2001, King et al. 2004). Asthma burden in some countries has warranted government intervention and consideration in their health strategies. Some estimates have stated that asthma may account for 1 in every 250 deaths worldwide (Masoli et al. 2004).

The prevalence of asthma among Egyptians ranged between $4.8 \%$ to 9.4 (Khallaf et al. 1993, Georgy et al. 2006, Halim et al. 2013). Despite a large volume of clinical and epidemiological researches within affected populations, the etiology and risk factors of these conditions remains poorly understood.

According to Levetin (1995) fungal spores are between $2 \mu \mathrm{m}$ and $100 \mu \mathrm{m}$. Eduard et al. (2001) have studied spores from aerosols by microscopy and they have discriminated fungal spores by size always greater than $1.5 \mu \mathrm{m}$. Table 1 presents aerodynamic diameters $\left(\mathrm{d}_{\mathrm{ae}}\right)$ of fungi in aerosols and shows that fungi are often present as particles with $d_{a e}$ between 2 and $6 \mu \mathrm{m}$. The small fungal particles in aerosols from pure fungal cultures have $d_{a e}$ of different sizes and are $\sim 0.4$ to 1.1 $\mu \mathrm{m}$ (Table 1).

Following the recent publications on the assessment of Egyptian fungi (Abdel-Azeem 2010) and published work on Lake Manzala (Rashad and Abdel-Azeem 2010) the objectives of this study were to: 1- close gaps in biodiversity knowledge on the diversity of Egyptian fungi, 2- determine the structure and diversity of aeromycobiota in Ashtoum El-Gamil protectorate, Lake Manzala, Egypt which has not never been the target of any study before and 3- raise the awareness about the adverse health effects due to exposure of air fungi. 
Table 1 Diameters (d) and aerodynamic diameters $\left(\mathrm{d}_{\mathrm{ae}}\right)$ of some common fungi.

\begin{tabular}{lllll}
\hline Species & $\begin{array}{l}\text { Spore } \\
\text { dimension }(\boldsymbol{\mu m})\end{array}$ & References & $\begin{array}{c}\mathbf{d}_{\mathbf{a e}} \text { of } \\
\text { spores }\end{array}$ & References \\
\hline Aspergillus flavus & $3.5-4.5$ & Domsch et al. (2007) & $3.3-3.8 \mathrm{a}$ & Madelin and Johnson (1992) \\
A. fumigatus & $2.5-3.0$ & Domsch et al. (2007) & $3.1 \mathrm{~b}$ & Lacey and Dutkiewicz (1976) \\
Cladosporium cladosporioides & $2-11$ & Domsch et al. (2007) & $2.3-2.5$ a & Madelin and Johnson (1992) \\
C. sphaerospermum & $3-7$ & Domsch et al. (2007) & 1.1 a & Madsen et al. (2009) \\
Penicillium chrysogenum & $2.8-4.0$ & Domsch et al. (2007) & 1.0 a & Madsen et al. (2006) \\
Stachybotrys chartarum & $7-12$ & Domsch et al. (2007) & 4.5 a & Sørensen et al. (1987) \\
Scopulariopsis brevicaulis & $5-9$ & Domsch et al. (2007) & $5.1-5.5$ a & Madelin and Johnson (1992 \\
Fungi & $>1.5$ & Eduard et al. (2001) & $2.1-3.3 \mathrm{~b}$ & Lin and Li (1996) \\
& & & $<2.1 \mathrm{~b}$ & Yeo and Kim (2002) \\
Fungal hyphal fragments & Length 5-100 & Green et al. (2005) & &
\end{tabular}

${ }^{a} \mathrm{~d}_{\mathrm{ac}}$ measured by an aerodynamic particle sizer.

${ }^{\circ}$ Peak number of cultivable organisms measured by an Andersen sampler.

\section{Materials \& Methods}

\section{Study area}

Ashtoum El-Gamil and Tanis island protectorate is located in western Port Said, about 13 $\mathrm{km}$ of the town, and covers an area of about $180 \mathrm{~km}^{2}$ lying completely inside Lake Manzala. Global Positioning system (GPS) of the protectorate's coordinates are: point A (N: $31^{\circ} 17^{\prime} 21^{\prime \prime}, \mathrm{E}: 32^{\circ} 13^{\prime}$ $\left.07^{\prime \prime}\right)$, point $\mathrm{B}\left(\mathrm{N}: 31^{\circ} 12^{\prime} 55^{\prime \prime}, \mathrm{E}: 32^{\circ} 13^{\prime} 45^{\prime \prime}\right)$, point $\mathrm{C}\left(\mathrm{N}: 31^{\circ} 12^{\prime} 20^{\prime \prime}, \mathrm{E}: 32^{\circ} 15^{\prime} 19^{\prime \prime}\right)$, point D (N:

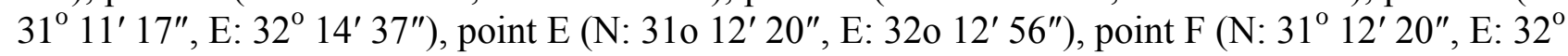
$\left.04^{\prime} 00^{\prime \prime}\right)$, point $\mathrm{G}\left(\mathrm{N}: 31^{\circ} 19^{\prime} 07^{\prime \prime}, \mathrm{E}: 32^{\circ} 04^{\prime} 00^{\prime \prime}\right)$, point $\mathrm{H}\left(\mathrm{N}: 31^{\circ} 18^{\prime} 26^{\prime \prime}, \mathrm{E}: 32^{\circ} 08^{\prime} 45^{\prime \prime}\right)$.

The climate affecting Lake Manzala is generally arid. The absolute minimum temperature ranges between $10^{\circ} \mathrm{C}$ in January and $23.7^{\circ} \mathrm{C}$ in August whereas the absolute maximum temperature ranges between $19^{\circ} \mathrm{C}$ in January and $33.3^{\circ} \mathrm{C}$ in August. Relative humidity is very similar throughout the year, the air being humid all the year round; relative humidity is rarely less than $70 \%$ or more than $80 \%$. The rainfall of Lake Manzala ranges between $47 \mathrm{~mm} /$ year and $88 \mathrm{~mm} /$ year; the rainy months are usually November, December, January and February. The total rainfall in any of these months varies between $5 \mathrm{~mm}$ and $20 \mathrm{~mm}$ and rarely amounts to $30 \mathrm{~mm}$. Wind velocity is almost uniform throughout the year; usually there is a gentle breeze. The wind velocity normally ranges between 10 and $20 \mathrm{~km} / \mathrm{h}$ (Zahran and Willis 2008).

Data such as monthly mean of temperature, relative humidity, wind speed and direction were kindly provided by Port-Said Metrological Station.

\section{Sampling, isolation and identification of fungi}

Five sites for spore trapping were selected in Ashtoum El-Gamil protectorate and designated as site 1 up to site 5 (Fig. 1 and Table 2). Fungi were sampled using a Microbio single-stage air sampler Model MB2 (Parrett LTD, UK). The sampler was operated for $10 \mathrm{~min}$ at a flow rate of 100 1/min. The sampler was loaded with Czapek's agar supplemented with $0.5 \%$ yeast extract (CYA), Potato Dextrose Agar (PDA) and Dichloran Glycerol Agar (DG-18) amended with Rose bengal $(1 / 1500)$ and chloramphenicol $(50 \mathrm{ppm})$ as isolation media. Between measurements the samplers were swabbed with $70 \%$ ethanol. At each stands, ten isolation plates were used for catching air fungi and were incubated at $28{ }^{\circ} \mathrm{C}$ for 7 days and the developing fungi were identified and counted. Samples were collected monthly over a period of 12 months between January 2012 and December 2012.

The fungi were identified morphologically and the aerosol concentrations $\left(\mathrm{CFU} / \mathrm{m}^{3}\right)$ were calculated. The number of $\mathrm{CFU}$ per cubic meter was calculated as: number of colonies $\mathrm{x}$ 1000/sampling time $\mathrm{x}$ velocity of air flow (Fanga et al. 2005). Taxonomic identification using morphology characteristics of fungal isolates down to the species level on standard media was mainly based on the following identification keys: Pitt (1980) for Penicillium (on Czapek Yeast 


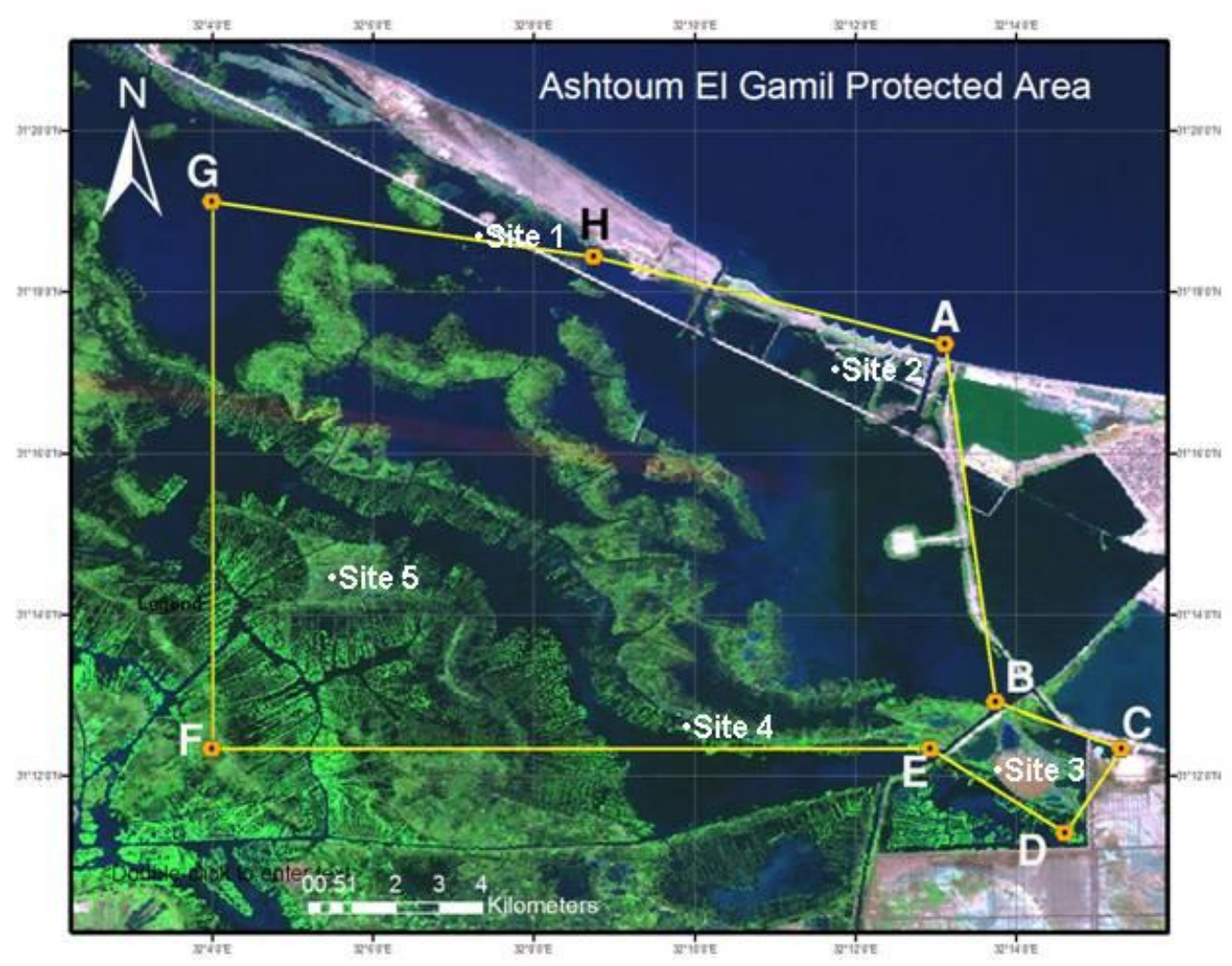

Fig. 1 - Map of Ashtoum El-Gamil Protectorate within Lake Mazala.

Table 2 GPS data of air sampling sites.

\begin{tabular}{llll}
\hline \multirow{2}{*}{ No. } & \multicolumn{1}{c}{ Site name } & \multicolumn{2}{c}{ GPS } \\
\cline { 3 - 4 } & & \multicolumn{1}{c}{$\mathrm{N}$} & \multicolumn{1}{c}{$\mathrm{E}$} \\
\hline 1 & Ashtoum-El-Gamil & $31^{\circ} 18^{\prime} 12.34^{\prime \prime}$ & $32^{\circ} 09^{\prime} 27.49^{\prime \prime}$ \\
2 & El-Gamil & $31^{\circ} 17^{\prime} 43.74^{\prime \prime}$ & $32^{\circ} 11^{\prime} 00.44^{\prime \prime}$ \\
3 & Kawm-Tanis & $31^{\circ} 12^{\prime} 0.53^{\prime \prime}$ & $32^{\circ} 14^{\prime} 4.57^{\prime \prime}$ \\
4 & Barr-El-Samariyyat & $31^{\circ} 12^{\prime} 22.82^{\prime \prime}$ & $32^{\circ} 11^{\prime} 22.49^{\prime \prime}$ \\
5 & Ligan & $31^{\circ} 14^{\prime} 26.49^{\prime \prime}$ & $32^{\circ} 05^{\prime} 35.60^{\prime \prime}$ \\
\hline
\end{tabular}

Extract Agar (CYA) ad Malt-Extract Agar (MEA)); Raper and Fennell (1965), Klich (2002) for Aspergillus (on Czapek Agar (CZ)); Ellis (1971, 1976) for dematiaceous hyphomycetes (Potato Carrot Agar (PCA)); Booth (1971) for Fusarium (Potato Dextrose Agar (PDA)), Domsch et al. (2007) for miscellaneous fungi (on MEA, PDA, CYA) and Guarro et al. (2012) for ascomycetes (on MEA, PDA, Oat Meal Agar (OA)).

The names of authors of fungal taxa are abbreviated according to Kirk and Ansell (1992). The systematic arrangement in the present list follows the latest system of classification appearing in the $10^{\text {th }}$ edition of Anisworth and Bisby's Dictionary of the Fungi (Kirk et al. 2008). Name corrections, authorities, and taxonomic assignments of all taxa reported in this work were checked against the Index Fungorum database (www. indexfungorum.org).

\section{Data analyses}

The frequency of isolated taxa is expressed as number of cases of isolation of each species out of the total number of isolation plates. To estimate the similarity of species composition among different sites, the similarity coefficient suggested by Sørensen (1948) have been applied, while species diversity is calculated as Simpson's diversity index (Lande, 1996). 


\section{Results and Discussion}

\section{Meteorological parameters}

During this study, the temperature ranged between 13.9 and $28{ }^{\circ} \mathrm{C}$, relative humidity ranged between 68.4 and $75.6 \%$ and wind speed records varied between 15.2 and $17.3 \mathrm{~km} / \mathrm{h}$. Wind direction through this study was mainly northern $(30 \%)$, western $(17 \%)$, northern east and northern west (15\% each), eastern (9\%), southern west (7\%), southern (5\%) and southern east (2 $\%)$.

\section{General features of isolated mycobiota}

From the 600 exposures that have been conducted, a total of 71780 fungi and 560 yeast colony-forming units (CFU) were recovered during the entire study. Mould colonies were assigned to 28 genera and 43 species from the different sites under investigation (Table 3 ).

The results show that Zygomycota were represented by three species $(6.9 \%$ of the total species number), teleomorphic Ascomycota (3 species, $6.9 \%$ ), anamorphic Ascomycota (36 species, $83.7 \%$ ) and Basidiomycota (1 species, $2.3 \%)$. The prevailing genera were Aspergillus $(8$ species $18.60 \%$ of the total taxa), Cladosporium, Penicillium and Ulocladium (three species each, $11.86 \%$ ), Alternaria, Fusarium (2 species each; $4.65 \%$ ). The remaining taxa were represented only by one species each.

Taxonomically, isolated species were assigned to 3 phyla with five classes, 11 orders, and 13 families (Table 4). Taxa with uncertain position were distributed among classes, orders and families. While order Eurotiales accommodates the greatest range of species (12 species) followed by Pleosporales (10 species), the remaining orders accommodate the lowest range between one to three species each. Family Trichocomaceae had the highest contribution to the isolated fungi (12 species out of 43) followed by Pleosporaceae (10 species), Davidiellaceae (3 species) and the remaining families were represented each only by one or two species.

The species genus ratio $(\mathrm{S} / \mathrm{G})$ per family however shows that family Trichocomaceae was the most diverse taxonomical rank by recording a ratio of 4 followed by Davidiellaceae (3), Nectriaceae (2) and Pleosporaceae (1.42). In view of species richness, site 5 showed the highest richness index of fungi species (species richness $=36$ ) among all studied sites and site 2 showed the poor species richness (25).

\section{The distribution of airborne fungi}

Site number 5 came first among all studied sites by recording $16750 \mathrm{CFU}$, while site number 2 showed the lowest amount (11960), as shown in figure 2. The distribution pattern of mycobiota based on the presence/absence in sites under investigation showed that recorded taxa could be tentatively classified into three groups. Group 1, comprises taxa of occurrence restricted to a single site (5 species) e.g. Phoma herbarum, Pithomyces chartarum and Stagonospora caricinella. Group 2, consists of species occurring in two or more sites (18) e.g. Mucor circinelloides, Paecilomyces variotii, Stemphylium piriforme and Curvularia lunata. Group 3, contains species of common occurrence to almost all sites (20 species) e.g. Aspergillus niger, A. flavus, Cladosporium cladosporioides and Ulocladium atrum.

Similarity coefficient values indicated that site 2 is a less similar to the other sites by showing the lowest similarity values. Other sites showed high similarity index values ranging from 0.84 to 0.94 .

The diversity of fungi was measured for each site by calculating Simpson's diversity index (Lande 1996). Based on the results, site 5 showed the highest diversity index of 0.937 while site 2 showed the lowest value $(0.918)$. 
Table 3 Fungi recorded, total counts (TC, calculated per 600 plates), percentage counts (\% C, calculated per total fungal catch), number of cases of isolation (NCI, out of 12 exposures) and occurrence remarks (OR) of all fungi recovered from the air of Ashtoum El-Gamil protectorate.

\begin{tabular}{|c|c|c|c|c|}
\hline Fungal species & $\mathrm{TC}$ & $\mathrm{C} \%$ & $\mathrm{NCI}$ & OR \\
\hline Alternaria alternata (Fr.) Keissl. & 3300 & 4.56 & 9.0 & $\mathrm{H}$ \\
\hline A. cheiranthi (Lib.) P.C. Bolle & 5700 & 7.88 & 12.0 & $\mathrm{H}$ \\
\hline Aspergillus flavus Link & 2900 & 4.01 & 8.0 & $\mathrm{H}$ \\
\hline A. fumigatus Fresen. & 4620 & 6.39 & 8.0 & $\mathrm{H}$ \\
\hline A. nidulans (Eidam) G. Winter & 1300 & 1.80 & 6.0 & $\mathrm{H}$ \\
\hline A. niger Tiegh & 9200 & 12.72 & 12.0 & $\mathrm{H}$ \\
\hline A. ochraceus G. Wilh. & 460 & 0.64 & 4.0 & M \\
\hline A. sydowii (Bainier \& Sartory) Thom \& Church & 680 & 0.94 & 3.0 & M \\
\hline A. terreus Thom & 4320 & 5.97 & 8.0 & $\mathrm{H}$ \\
\hline A. versicolor (Vuill.) Tirab. & 360 & 0.50 & 3.0 & M \\
\hline Aurobasidium pullulans (de Bary) Arnaud & 5960 & 8.24 & 11.0 & $\mathrm{H}$ \\
\hline Candida tropicalis (Castell.) Berkhout & 340 & 0.47 & 9.0 & $\mathrm{H}$ \\
\hline Chaetomium globosum Kunze & 300 & 0.41 & 3.0 & M \\
\hline Cladosporium cladosporioides (Fresen.) G.A. de Vries & 7740 & 10.70 & 10.0 & $\mathrm{H}$ \\
\hline C. herbarum (Pers.) Link & 3320 & 4.59 & 8.0 & $\mathrm{H}$ \\
\hline C. sphaerospermum Penz. & 900 & 1.24 & 4.0 & M \\
\hline Curvularia lunata (Wakker) Boedijn & 140 & 0.19 & 4.0 & M \\
\hline Drechslera hawaiiensis Bugnic. ex Subram. \& B.L. Jain & 160 & 0.22 & 5.0 & M \\
\hline Epicoccum nigrum Link & 6040 & 8.35 & 10.0 & $\mathrm{H}$ \\
\hline Fusarium oxysporum Schltdl. & 280 & 0.39 & 6.0 & $\mathrm{H}$ \\
\hline F. solani (Mart.) Sacc. & 100 & 0.14 & 4.0 & M \\
\hline Gymnascella dankaliensis (Castell.) Currah & 40 & 0.06 & 1.0 & $\mathrm{~L}$ \\
\hline Lichtheimia corymbifera (Cohn) Vuill. & 120 & 0.17 & 4.0 & M \\
\hline Microascus brevicaulis S.P. Abbott & 160 & 0.22 & 5.0 & M \\
\hline Mucor circinelloides Tiegh. & 220 & 0.30 & 3.0 & M \\
\hline Paecilomyces variotii Bainier & 260 & 0.36 & 2.0 & $\mathrm{~L}$ \\
\hline Penicillium chrysogenum Thom & 5460 & 7.55 & 12.0 & $\mathrm{H}$ \\
\hline P. funiculosum Thom & 1220 & 1.69 & 7.0 & $\mathrm{H}$ \\
\hline P. roquefortii Thom & 480 & 0.66 & 6.0 & $\mathrm{H}$ \\
\hline Phoma herbarum Westend. & 120 & 0.17 & 2.0 & $\mathrm{~L}$ \\
\hline Pithomyces chartarum (Berk. \& M.A. Curtis) M.B. Ellis & 100 & 0.14 & 2.0 & $\mathrm{~L}$ \\
\hline Rhizopus stolonifer (Ehrenb.) Vuill. & 1180 & 1.63 & 12.0 & $\mathrm{H}$ \\
\hline Rhodotorula glutinis (Fresen.) F.C. Harrison & 560 & 0.77 & 6.0 & $\mathrm{H}$ \\
\hline Sarocladium strictum (W. Gams) Summerb. & 420 & 0.58 & 3.0 & M \\
\hline Scopulariopsis chartarum (G. Sm.) F.J. Morton \& G. Sm. & 220 & 0.30 & 3.0 & M \\
\hline Stachybotrys chartarum (Ehrenb.) S. Hughes & 280 & 0.39 & 3.0 & M \\
\hline Stagonospora caricinella Brunaud & 20 & 0.03 & 1.0 & $\mathrm{~L}$ \\
\hline Stemphylium piriforme Bonorden & 180 & 0.25 & 3.0 & M \\
\hline Trichoderma koningii Oudem. & 1500 & 2.07 & 5.0 & M \\
\hline Trichothecium roseum (Pers.) Link & 60 & 0.08 & 1.0 & $\mathrm{~L}$ \\
\hline Ulocladium atrum Preuss. & 900 & 1.24 & 9.0 & $\mathrm{H}$ \\
\hline U. chartarum (Preuss) E.G. Simmons & 220 & 0.30 & 6.0 & $\mathrm{H}$ \\
\hline U. oudemansii E.G. Simmons & 500 & 0.69 & 5.0 & M \\
\hline Total & 72340 & 100.00 & 12 & \\
\hline
\end{tabular}

Occurrence remarks (OR): $\mathrm{H}$ : high, 6-12 of the exposures; M: moderate, 3-5 of the exposures; L: low, 1-2 of the exposures. 
Table 4 Taxonomic assignment of the isolated taxa according to Kirk et al. (2008)

\begin{tabular}{|c|c|c|c|c|c|}
\hline Phylum & Class & Order & Family & Genus & Species \\
\hline \multirow{3}{*}{ Zygomycota } & \multirow{3}{*}{ Incertae sedis } & \multirow{3}{*}{ Mucorales } & Lichtheimiaceae & 1 & 1 \\
\hline & & & Mucoraceae & 1 & 1 \\
\hline & & & Rhizopodaceae & 1 & 1 \\
\hline \multirow{13}{*}{ Ascomycota } & \multirow{5}{*}{ Dothideomycetes } & Capnodiales & Davidiellaceae & 1 & 3 \\
\hline & & Dothidiales & Dothioraceae & 1 & 1 \\
\hline & & \multirow{3}{*}{ Pleosporales } & Phaeosphaeriaceae & 1 & 1 \\
\hline & & & Pleosporaceae & 7 & 10 \\
\hline & & & Incertae sedis & 1 & 1 \\
\hline & \multirow{2}{*}{ Eurotiomycetes } & Eurotiales & Trichocomaceae & 3 & 12 \\
\hline & & Onygenales & Gymnoascaceae & 1 & 1 \\
\hline & \multirow[t]{2}{*}{ Saccharomycetes } & Saccharomycetales & Incertae sedis & 1 & 1 \\
\hline & & & Hypocreaceae & 1 & 1 \\
\hline & \multirow{4}{*}{ Sordariomycetes } & Hypocreales & Incertae sedis & 3 & 3 \\
\hline & & & Nectriaceae & 1 & 2 \\
\hline & & Microascales & Microascaceae & 2 & 2 \\
\hline & & Sordariales & Chaetomiaceae & 1 & 1 \\
\hline Basidiomycota & Microbotryomycetes & Sporidiobolales & Incertae sedis & 1 & 1 \\
\hline Total & 5 & 11 & 13 & 28 & 43 \\
\hline
\end{tabular}

The greatest colony count was attributed to Aspergillus niger $(12.7 \%$ of the total isolate number), Cladosporium cladosporioides (10.69\%), Epicoccum nigrum (8.34\%), Alternaria cheiranthi (7.87 \%), Penicillium chrysogenum (7.54\%), Aspergillus fumigatus (6.38\%), Aspergillus terreus (5.97\%), and Alternata alternata (4.56\%) respectively. Figure 3 represents the ten major genera observed in the study as they represent more than $95 \%$ of total colony counts obtained (Table 2). The greatest total colony count was attributed to Aspergillus with 35\% followed by Cladosporium, Alternaria and Penicillium with 17, 13 and 10\% respectively (Table 3, Fig. 3).

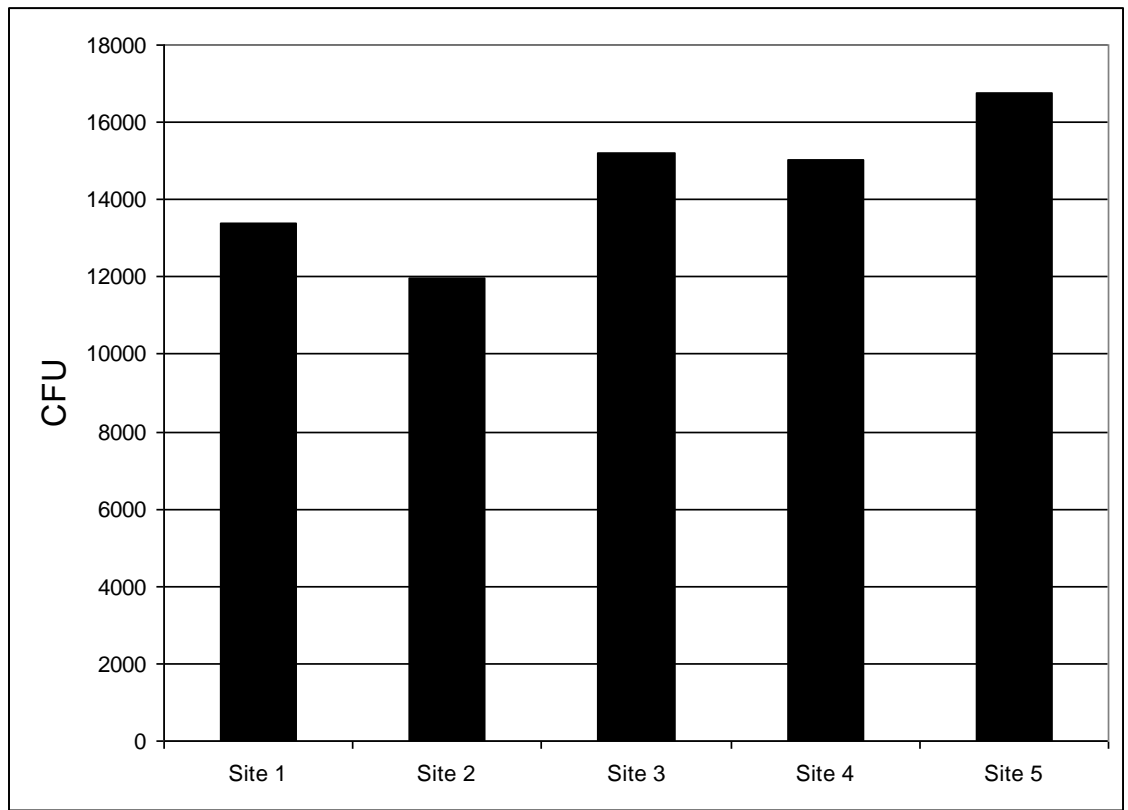

Fig. 2 - Total fungal counts in the study sites. 


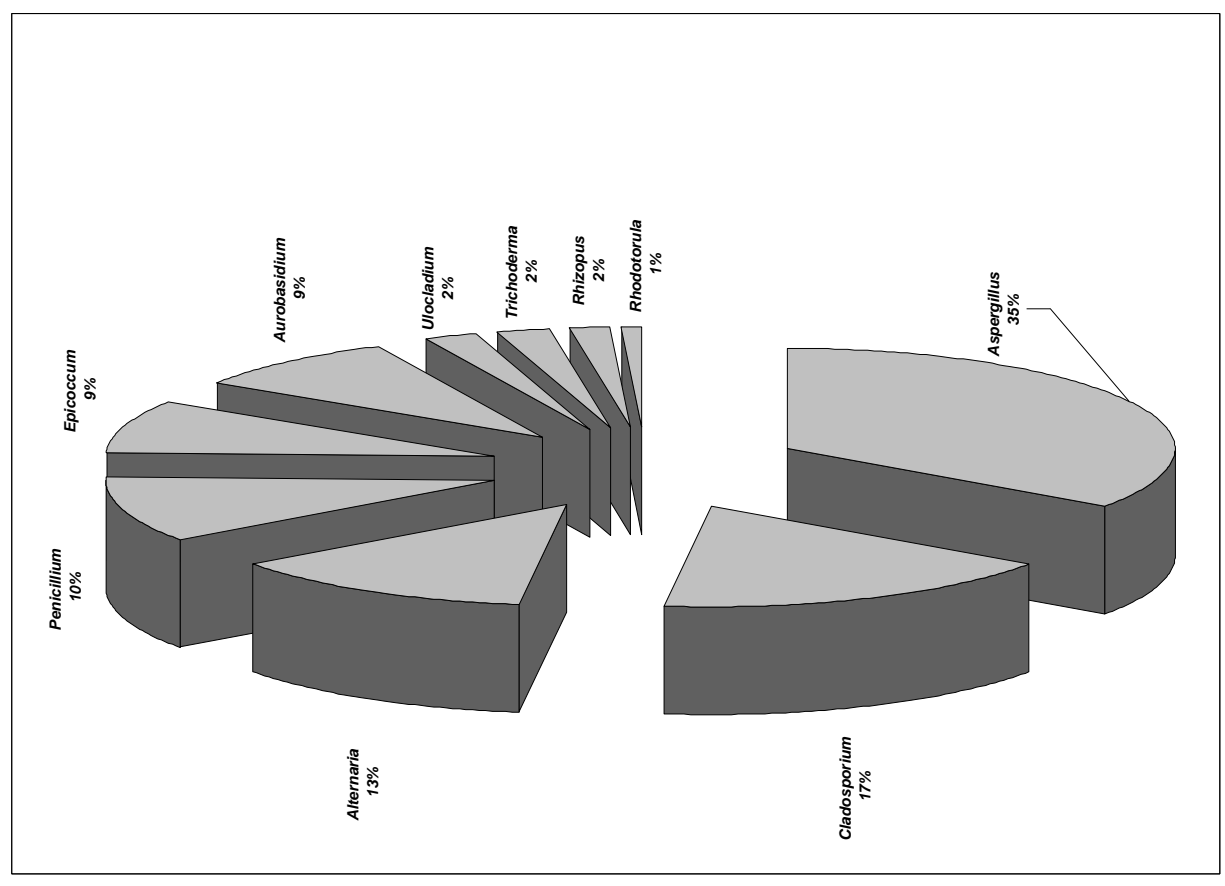

Fig. 3 - Relative contributions (\% of total colony count) of the major airborne fungi in Manzala lagoon, Egypt.

Aspergillus, Alternaria and Penicillium occurred every month of the entire study (12 months), followed by Cladosporium (10 months), Ulocladium (9 months) and Fusarium (6 months). During the entire year of 2012, the number of monthly recorded species showed that August recorded 24 species while September recorded 10 species only. Aspergillus, showed one peak in August while Cladosporium and Alternaria peaked in June (Fig. 4). Lake Manzala airborne fungal counts increased with temperature and decreased with rainfall and relative humidity and this in agreement with findings of Awad (2005).

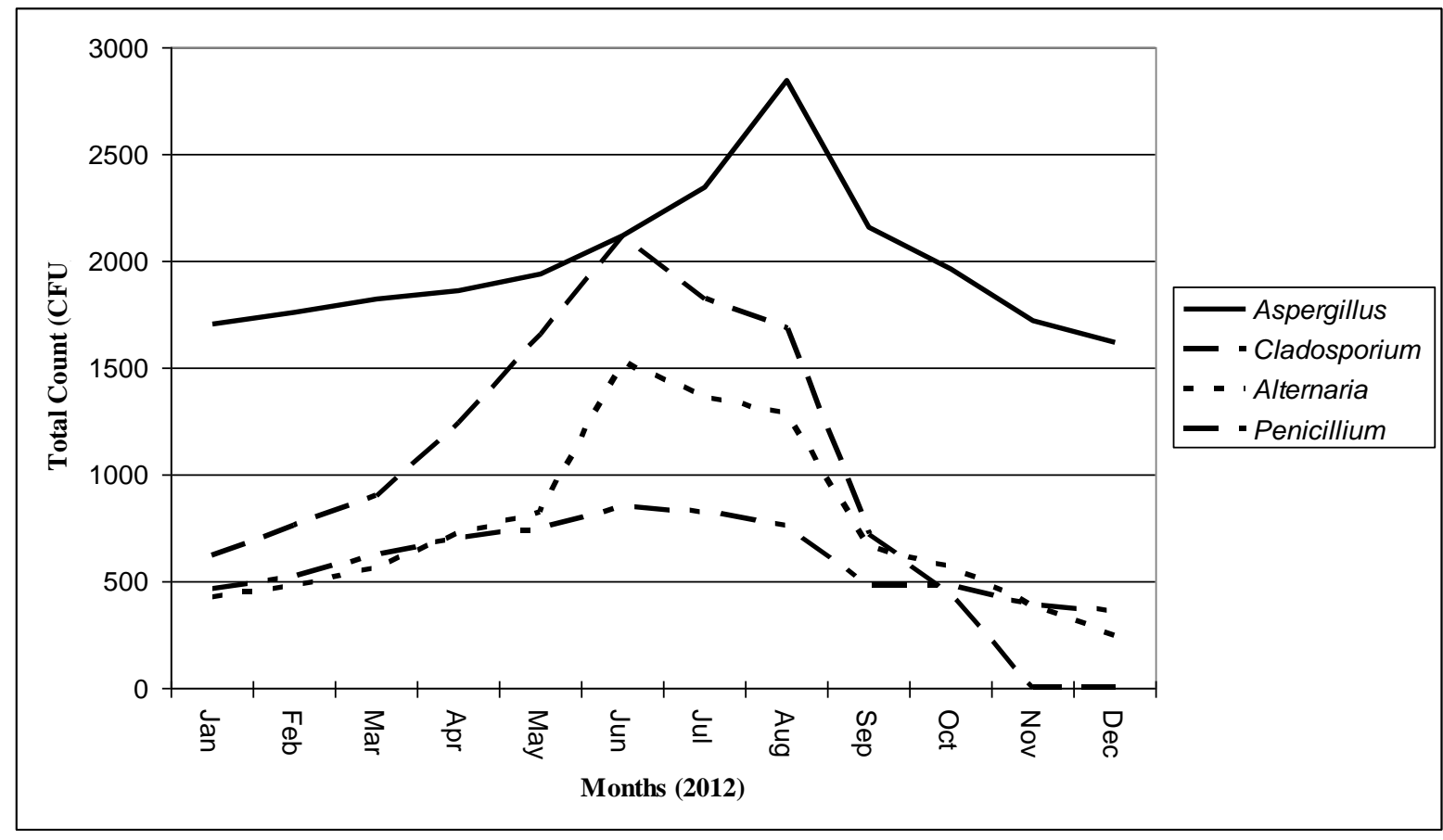

Fig. 4 - Dominant genera recorded every month throughout the study course. 
Vegetation of Lake Manzala is typically Mediterranean (Maswada and Elzaawely, 2013) which includes halophytic and helophytic species growing mainly on shores and islands of the lake. Water habitat of Lake Manzala is characterized by five dominant hydrophytes and four associates (Khedr 1989). Grasses e.g. Phragmites australis is widespread and its community occurs in all islands where it forms dense thickets along shore-lines with surface deposits of sand and silt (Zahran et al. 1989).

Vegetation plays a major role in addition of different fungal types into the air and their numbers vary according to vegetation type and weather conditions (Awad 2005). Some of the most the abundant spores found in the atmosphere have the capability to interact with plants, where they may become endophytes first and saprobes later. These fungi are extremely abundant as endophytes in grasses and other plant taxa, and are likely to have important roles as saprobes, in plant decomposition and nutrient cycling. Furthermore, the spores of these fungi also interact with human immune systems, being respiratory allergens (Vázquez de Aldana et al. 2013).

Many studies have been performed to identify the concentrations and types of aeromycobiota in outdoors in Egypt. Outdoor concentrations averaged $540 \mathrm{CFU} / \mathrm{m}^{3}$ across the US (Shelton et al. 2002), and $1,042 \mathrm{CFU} / \mathrm{m}^{3}$ in Latrobe Valley, Australia (Garrett et al. 1997). In the present study, fungal concentrations, $120.6 \mathrm{CFU} / \mathrm{m}^{3}$, were found to be higher than those reported in some studies in different localities in Egypt. Fungal concentrations were found in the range of 25-222 CFU/m $\mathrm{m}^{3}$ outdoors at the coastal buildings in Damietta (El-Morsy 2006).

There are no numeric guidelines for outdoor airborne fungi, however a number of numeric guidelines have been proposed throughout the years (Li and Kuo 1993, WHO 1998, Wu et al. 2000), but none of them are currently widely accepted by the scientific community (Codina et al. 2008). In comparison with previous studies in Egypt, our findings indicate that the Lake Manzala air $\left(120.6 \mathrm{CFU} / \mathrm{m}^{3}\right)$ had much higher than acceptable levels of fungi. In the present study, concentrations of fungal spores in the size range of $\leq 5 \mu \mathrm{m}$ were the predominant fraction. In most parts of the world the main core of fungal aerosols is likely to be similar, but the dominance of genera may differ from one area to another depending on geographical location, local sources, and climatic conditions (Abdel Wahid et al. 1996). Qualitative determination of fungi may be more useful than determining concentrations, as many species may have health effects. The frequent detection of Aspergillus spp., Penicillium, and Cladosporium is attributed to their ready dissemination into the air. These findings in our study are similar to those observed in other geographical locations in Italy (Dacarro et al. 2003), Egypt (El-Morsy 2006, Abdel Hameed et al. 2009) and Florida, USA (Codina et al. 2008).

Horner et al. (2004) grouped fungi into three categories with different ecological relevance: (1) phylloplane fungi (Cladosporium, Curvularia and Alternaria); (2) soil fungi (Penicillium, Paecilomyces and Aspergillus), and (3), water indicator fungi (Chaetomium, Stachybotrys and Ulocladium). In the present study water indicator fungi were found in low counts, and their presence associated with rain time or the presence of damped materials, however phyloplane and soil fungi were found in higher counts during the collection of air samples (January 2012 to December 2012) . Taxa such as Cladosporium, Penicillium and Alternaria could increase the risk of asthma and allergic rhinitis and allergic alveolitis (Lacey and Dutkiewicz 1994). While Sarocladium (Acremonium), Alternaria, Aspergillus, Cladosporium, Fusarium, Paecilomyces, Penicillium, Stachybotrys and Trichoderma are well known mycotoxin producers (Davis 2013). Both of Aspergillus flavus and A. fumigatus can lead to aspergillosis (Abarca 2000). As the potential implications of the fungal contamination on health have not been studied in Egypt, it should to be reported that exposure to such concentrations of this study $\left(120.6 \mathrm{CFU} / \mathrm{m}^{3}\right)$ and types is a risk factor for resident's respiratory symptoms. Fungi impact human health in four different ways as they can infect humans or act as allergens or can be toxic or can cause inflammatory reactions (Fischer and Dott 2003).

Some fungal spores such as Cladosporium and Alternaria are considered as integral parts of the outdoor air and they comprise more than $29 \%$ of the total fungal load in Lake Manzala. These spores are subject to the individual geoclimatic characteristics of their surrounding 
environment. Aerobiology studies suggest that the release of spores is subject to factors such as species, texture and air velocity above the contaminated surfaces or vibrations that cause their release (Górny et al. 2002). Our results may be clarify why the prevalence of asthma in Ismailia and Port Said governorates increased dramatically between $9.6 \%$ and $11.4 \%$ respectively (ElBaz, 1994; Halim et al. 2013).

\section{Conclusions}

This work has shown that fungi which may cause diseases of the respiratory system and have the power to produce mycotoxins were encountered frequently in the research areas. Lake Manzala with its climatic conditions and vegetation presents a suitable habitat for the increase of fungi. The presence of fungal spores in air, in spite of their counts, may raise arguments about their role in health complaints in a particular region, i.e., the fungal concentration may be low but the predominant aeroallergen may be dangerous. Asthma is a multi-factorial condition and environmental factors such as particulate matter and other contaminants coupled with possible genetic predisposition, behavioral and social factors interacted to produce the high asthma prevalence. A comprehensive model of factors that contribute to asthma in the region is needed and this can be a useful tool for planning efforts and disease prevention. The obtained results indicated that the fungi of air should be considered when the quality of Egyptian air is assessed.

\section{Acknowledgments}

The authors wish to express their gratitude to Miss Fatma Mahmoud Salem, Systematic Mycology laboratory, Botany and Microbiology Department, Faculty of Science, University of Suez Canal for her help in preparation of manuscript and figures.

\section{References}

Abarca M. 2000 - Taxonomy and identification of the species involved in nosocomial aspergillosis. Revista Iberoamericana de Micología 17, 79-84.

Abdel-Azeem AM. 2003 - Ecological and taxonomical studies on ascospore-producing fungi in Egypt. Ph D thesis, Suez Canal University, Ismailia, Egypt.

Abdel-Azeem AM. 2009 - Operation Wallacea in Egypt. I- A preliminary study on diversity of fungi in the world heritage site of Saint Katherine, Egypt. Assiut University Journal of Botany 38(1), 29-54.

Abdel-Azeem AM. 2010 - The history, fungal biodiversity, conservation, and future perspectives for mycology in Egypt. IMA Fungus (1) 2, 123-142.

Abdel-Fattah H, Moubasher A, Swelim M. 1981 - Studies on air-borne fungi at Qena. II. Diurnal fluctuations. Zeitschrift für allgemeine Mikrobiologie 21, 177-9.

Abdel-Hafez SI, Shoreit A, Abdel-Hafez IA, EL-Maghraby OM. 1986 - Mycoflora and mycotoxin producing fungi of air-dust particles from Egypt. Mycopathologia 93, 25-32.

Abdel Hameed A, Khoder M. 2001-Suspended particulates and bioaerosols emitted from an agricultural non-point source. Journal of Environmental Monitoring 3, $206-9$.

Abdel Hameed A, Khoder M, Emad A. 2007 - Fertile fungal spores collected on different faced surfaces in the atmosphere of Giza, Egypt. Aerobiologia 23, 47-57.

Abdel Hameed A, Farag S, El Abagy M, Mansour F. 1999 - Airborne Gram negative bacteria in air at three occupational sites in greater Cairo. Egyptian Journal of Microbiology 34, 58394.

Abdel Hameed A, Khoder MI, Yuosra S, Osman AM, Ghanem S. 2009 - Diurnal distribution of airborne bacteria and fungi in the atmosphere of Helwan area, Egypt. Science of the Total Environment 407, 6217-6222.

Abdul Wahid A, Moustafa A, Moustafa A. 1996 - Fungal population in the atmosphere of Ismailia City. Aerobiologia 12, 249-55. 
Abu-El-Souod S. 1974 - Studies on fungus air-spora in Egypt. Ph.D. Thesis, Fac. Sci., Assiut University.

Awad AA. 2005 - Vegetation: A source of air fungal bio-contaminant. Aerobiologia 21, 53-61.

Booth C. 1971 - Fusarium, laboratory guide to the identification of the major species. Kew, Surrey, England: Commonwealth Mycological Institute.

Bush RK. 2001 - Introduction. In: Environmental Asthma (Bush RK, ed). New York: Marcel Dekker, 1-12.

Codina R, Fox R, Lockey R, DeMarco P, Bagg A. 2008 - Typical levels of airborne fungal spores in houses without obvious moisture problems during a rainy season in Florida, USA. Journal of Investigational Allergology and Clinical Immunology 18, 156-162.

Cuijpers CEJ, Swaen GMH, Wesseling G, Sturmans F, Wouters EFM. 1995 - Adverse effects of the indoor environment on respiratory health in primary school children. Environmental Research 68, 11-23.

Dacarro C, Picco M, Grisoli P, Rodolfi M. 2003 - Determination of aerial microbiological contamination in scholastic sports environments. Journal of Applied Microbiology 95, 904 912.

Davis PJ. 2013 - Molds, toxic molds, and indoor air quality. California Research Bureau (CRB), California State Library: Sacramento, CA, USA. Available online: http://www.library.ca.gov/crb/01/notes/v8n1.pdf (accessed on 19 July 2013).

Domsch KH, Gams W, Anderson T-H. 2007 - Compendium of soil fungi. Eching : IHW-Verl, $672 \mathrm{p}$.

Eduard W, Blomquist G, Nielsen BH, Kulvik Heldal K. 2001 - Recognition errors in the quantification of microorganisms by fluorescence microscopy. Annals of Occupational Hygiene 45, 493-8.

El-Baz H. 1994 - Study of the prevalence of bronchial asthma and related risk factors in primary school children in El-Salam area in Port Said. M Sc. thesis, Faculty of Medicine, Suez Canal University.

Ellis MB. 1971 - Dematiaceous hyphomycetes (p. 608). Kew, Surrey, England: Commonwealth Mycological Institute.

Ellis MB. 1976 - More dematiaceous hyphomycetes (p. 507). Kew, Surrey, England: Commonwealth Mycological Institute.

El-Morsy E. 2006 - Preliminary survey of indoor and outdoor airborne microfungi at coastal buildings in Egypt. Aerobiologia 22, 197-210.

Fanga Z, Ouyanga Z, Hub L, Wanga X, Zhenga H, Lina X. 2005 - Culturable airborne fungi in outdoor environments in Beijing, China. Science of the Total Environment 350, 47-58.

Fischer G, Dott W. 2003 - Relevance of airborne fungi and their secondary metabolites for environmental, occupational and indoor hygiene. Archives of Microbiology 179, 75-82.

Flannigan B, McCabe EM, McGarry F. 1991 - Allergic and toxigenic micro-organisms in houses. Journal of Applied Bacteriology Symposium Supplement 70, 61S-73S.

Garrett M, Hooper B, Cole F, Hooper M. 1997 - Airborne fungal spores in 80 homes in the Latrobe valley, Australia: Levels, seasonality and indoor-outdoor relationship. Aerobiologia 13, 121-126.

Georgy V, Fahim HI, El-Gaafary M. 2006 - Prevalence and socioeconomic associations of asthma and allergic rhinitis in northern Africa. European Respiratory Journal 28, 756-62.

Górny RL, Reponen T, Willeke K, Schmechel D, Robine E, Boissier M, Grinshpun SA. 2002 Fungal fragments as indoor air biocontaminants. Applied and Environmental Microbiology 68 (7), 3522-3531.

Green BJ, Sercombe JK, Tovey ER. 2005 - Fungal fragments and undocumented conidia function as new aeroallergen source. Journal of Allergy and Clinical Immunology 115, 1043-8.

Guarro J, Gene J, Stchigel AM, Figueras MJ. 2012 - Atlas of soil ascomycetes. Issue 10 of CBS biodiversity series, Holland. 
Halim WB, Khalil KA, Sobhy SA, Hasb-Allah SA. 2013 - Prevalence of bronchial asthma among secondary schools students at Abu Khalifa village-Ismailia Governorate. Medical Journal of Cairo University 81 (2), 19-24.

Horner WE, Helbling A, Salvaggio JE, Lehrer SB. 1995 - Fungal allergens. Clinical Microbiology Reviews 8, 161-179.

Horner W, Worthan A, Morey P. 2004 - Air and dust borne mycoflora in houses free of water damage and fungal growth. Applied and Environmental Microbiology 70, 394-6400.

Hu FB, Persky V, Flay BR, Richardson J. 1997 - An epidemiological study of asthma prevalence and related factors among young adult. British Medical Journal 34, 67-76.

Ismail M, Abdel-Hafez S, Moharram A. 2002 - Aeromycobiota of western desert of Egypt. African Journal of Science and Technology 3,1-9.

Khallaf N, El-Ansary S, Hassan M. 1993 - Acute respiratory infections: sentinel survey in Egypt. National ARI control Programme, Child Survival Project, Ministry of Health, Bab El Louk, Cairo, Egypt.

Khedr A. 1989 - Ecological Studies on Lake Manzala, Egypt. MSc Thesis, Fac. Sci., Mansoura Univ., Egypt.

King ME, Mannino DM, Holguin F. 2004 - Risk factors for asthma incidence. A review of recent prospective evidence. Panminerva Medica 46,97-110.

Kirk PM, Ansell AE. 1992 - Authors of Fungal Names. Kew: CAB International, 95 p.

Kirk PM, Cannon PF, Minter DW, Stalpers JA. 2008 - Ainsworth \& Bisby's Dictionary of the Fungi. $10^{\text {th }}$ edn. CAB International, Wallingford, UK.

Klich MA. 2002 - Identification of common Aspergillus species. Centralbureau voor Schimmelcultures, Utrecht, Netherlands, $116 \mathrm{pp}$.

Kowalski W, Bahnfleth WP. 1998 - Airborne respiratory diseases and technologies for control of microbes. Heating Piping Air Conditioning 70 (6), 34-48

Lacey J, Dutkiewicz J. 1976 - Isolation of actinomycetes and fungi from mouldy hay using a sedimentation chamber. Journal of Applied Bacteriology 41, 315-9.

Lacey J, Dutkiewicz J. 1994 - Bioaerosols and occupational lung disease. Journal of Aerosol Science 25, 1371-1404.

Lande R. 1996 - Statistics and partitioning of species diversity, and similarity among multiple communities. Oikos 76, 5-13.

Levetin E. 1995 - Fungi. In: Bioaerosols (eds. Burge H.), Lewis Publishers/CRC Press: Boca Raton, pp. 87-120.

Li Ch, Kuo Y. 1993 - Microbiological indoor air quality in subtropical areas. Environment International 19, 233-239.

Lin WH, Li CS. 1996 - Size characteristics of fungus allergens in the subtropical climate. Aerosol Science and Technology 25, 93-100.

Madelin TM, Johnson HE. 1992 - Fungal and actinomycetes spore aerosols measured at different humidities with an aerodynamic particle sizer. Journal of Applied Bacteriology 72, 400-9.

Madsen AM, Kruse P, Schneider T. 2006 - Characterization of microbial particle release from biomass and building material surfaces for inhalation exposure risk assessment. Annals of Occupational Hygiene 50, 175-87.

Madsen AM, Schlünssen V, Olsen T, Sigsgaard T, Avci H. 2009 - Airborne fungal and bacterial components in PM1 dust from biofuel plants. Annals of Occupational Hygiene 53, 749757.

Masoli M, Fabian D, Holt S, Beasley R. 2004 - Global Initiative for Asthma (GINA) program: The global burden of asthma: Executive summary of the GINA Dissemination Committee report. Allergy 59, 469-478.

Maswada HF, Elzaawely AA. 2013 - Ecological investigation of three geophytes in the Deltaic Mediterranean coast of Egypt. Pakistan Journal of Biological Science 16 (23), 1662-1674. 
Moubasher AH, Moustafa AF. 1974 - Airborne fungi at Assiut, Egypt. Egyptian Journal of Botany 17, 135-149.

Moustafa AF. 1971 - Studies on Egyptian fungi in soil and air. Ph D thesis, University of Assiut, Egypt.

Pitt JI. 1980-[1979] - The genus Penicillium and its teleomorphic states Eupenicillium and Talaromyces. London:Academic.

Raper KB, Fennell DI. 1965 - The genus Aspergillus. Baltimore: Williams \& Wilkins.

Rashad HM, Abdel-Azeem AM. 2010 - Lake Manzala, Egypt: A bibliography. Assiut University Journal of Botany 39(1), 253-289.

Ross MA, Curtis L, Scheff PA, Hryhorczuk DO, Ramakrishnan V, Wadden RA, Persky VW. 2000 - Association of asthma symptoms and severity with indoor bioaerosols. Allergy 55, $705-711$.

Saad SI. 1958 - Studies in atmospheric pollen grains and fungus spores at Alexandria. II. Pollen and spore deposition in relation to weather conditions and diurnal variation in the incidence of pollen. Egyptian Journal of Botany 1, 63-79.

Shelton G, Kirkland H, Dana Flanders W, Morris K. 2002 - Profiles of airborne fungi in buildings and outdoor environments in the United States. Applied and Environmental Microbiology 68, 1743-1753.

Sørensen T. 1948 - A method of establishing groups of equal amplitude in plant sociology based on similarity of species content and its application to analyses of the vegetation on Danish commons. Videnski Selskab Biologiske Skrifter 5, 1-34.

Sørensen WG, Frazer DG, Jarvis BB, Simpson J, Robinson VA. 1987 - Trichothecene mycotoxins in aerosolized conidia of Stachybotrys atra. Applied and Environmental Microbiology 53, 1370-5.

Stanley DJ. 1988 - Subsidence in the northeastern Nile Delta: rapid rates, possible cause, and consequence. Science 240, 497-500.

Tahoun SA. 2007 - Environmental perspectives of the Port Said area. Final report of plan of action for an integrated coastal zone management in the area of Port Said (Egypt), pp 230.

Vázquez de Aldana BR, Bills G, Zabalgogeazcoa I. 2013 - Are endophytes an important link between airborne spores and allergen exposure?. Fungal Diversity 60, 33-42.

WHO Regional Publications 1998 - European Series No 31: Indoor Air Quality: Biological Contaminants; World Health Organization: Copenhagen, Denmark.

Wu P-C, Su H-J, Lin C-Y. 2000 - Characteristic of indoor and outdoor airborne fungi at suburban and urban homes in two seasons. Science of the Total Environment 253, 111118.

Yeo HG, Kim JH. 2002 - SPM and fungal spores in the ambient air of west Korea during the Asian dust (Yellow sand) period. Atmospheric Environment 36, 5437-42.

Zahran MA. 2010 - Climate-vegetation: afro-Asian Mediterranean and Red Sea Coastal lands. Plant and Vegetation 4, 1-103.

Zahran MA, Willis AJ. 2008 - The Vegetation of Egypt (plant and vegetation). Springer-Verlag, New York Inc., United States.

Zahran MA, Abu Ziada ME, El-Demerdash MA, Khedr AA. 1989 - A note on the vegetation on islands in Lake Manzala, Egypt. Vegetatio 85, 83-88.

Zaky MK. 1960 - Studies on the dissemination of pollen grains and spores in the Cairo area. MSc thesis, Cairo University. 